\title{
Application of Artificial Neural Networks for Yield Modeling of Winter Rapeseed Based on Combined Quantitative and Qualitative Data
}

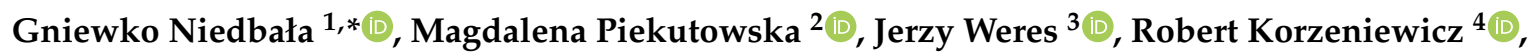

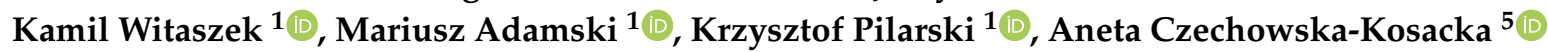 \\ and Anna Krysztofiak-Kaniewska ${ }^{6}$ (D) \\ 1 Institute of Biosystems Engineering, Faculty of Agronomy and Bioengineering, Poznań University of Life \\ Sciences, Wojska Polskiego 50, 60-627 Poznań, Poland; kamil.witaszek@up.poznan.pl (K.W.); \\ mariusz.adamski1@wp.pl (M.A.); krzysztof.pilarski@up.poznan.pl (K.P.) \\ 2 Department of Agrobiotechnology, Faculty of Mechanical Engineering, Koszalin University of Technology, \\ Racławicka 15-17, 75-620 Koszalin, Poland; magdalena.piekutowska@poczta.fm \\ 3 Faculty of Information Technology and Visual Communication, Collegium Da Vinci, Tadeusza Kutrzeby 10, \\ 61-719 Poznań, Poland; weres@up.poznan.pl \\ 4 Department of Silviculture, Faculty of Forestry, Poznań University of Life Sciences, Wojska Polskiego 71a, \\ 60-625 Poznań, Poland; korzon@up.poznan.pl \\ 5 Institute of Environmental Protection Engineering, Faculty of Environmental Engineering, Lublin University \\ of Technology, Nadbystrzycka 40B, 20-618 Lublin, Poland; a.czechowska-kosacka@pollub.pl \\ 6 Department of Forest Engineering, Faculty of Forestry, Poznań University of Life Sciences, Wojska Polskiego \\ 71c, 60-625 Poznań, Poland; anna.krysztofiak-kaniewska@up.poznan.pl \\ * Correspondence: gniewko@up.poznan.pl
}

Received: 28 October 2019; Accepted: 17 November 2019; Published: 20 November 2019

\begin{abstract}
Rapeseed is considered as one of the most important oilseed crops in the world. Vegetable oil obtained from rapeseed is a valuable raw material for the food and energy industry as well as for industrial applications. Compared to other vegetable oils, it has a lower concentration of saturated fatty acids $(5 \%-10 \%)$, a higher content of monounsaturated fatty acids $(44 \%-75 \%)$, and a moderate content of alpha-linolenic acid (9\%-13\%). Overall, rapeseed is grown in all continents on an industrial scale, so there is a growing need to predict yield before harvest. A combination of quantitative and qualitative data were used in this work in order to build three independent prediction models, on the basis of which yield simulations were carried out. Empirical data collected during field tests carried out in 2008-2015 were used to build three models, QQWR15_4, QQWR31_5, and QQWR30_6. Each model was composed of a different number of independent variables, ranging from 21 to 27. The lowest MAPE (mean absolute percentage error) yield prediction error corresponded to QQWR31_5, it was $6.88 \%$, and the coefficient of determination $R^{2}$ was 0.69 . As a result of the sensitivity analysis of the neural network, the most important independent variable influencing the final rapeseed yield was indicated, and for all the analyzed models it was "The kind of sowing date in the previous year" (KSD_PY).
\end{abstract}

Keywords: winter rapeseed; artificial neural networks; machine learning; yield prediction; yield simulation; MLP (multi-layer perceptron) network; sensitivity analysis; precision agriculture; sustainable agriculture; sustainability

\section{Introduction}

Vegetable oil obtained from rapeseed is an important element of food and a balanced diet. It is also used for the production of biodiesel, in the form of rapeseed methyl esters (RME) and is also 
an essential industrial raw material. These main applications of rapeseed are associated with a high content of protein, carbohydrates, and triacylglycerol (TAG) [1-4]. In view of the above, the cultivated land used for rapeseed must compete between food, industrial, and energy purposes $[5,6]$. Thus, production planning and forecasting of rapeseed yield is crucial in the whole cultivation process. This is directly related to the financial policy and sales deadline strategy adopted by rapeseed producers.

The 2017 world rapeseed production amounted to 76,238,340 tons, with an average yield of $2.19 \mathrm{tha}^{-1}$ on the total crop land of $34,740,403 \mathrm{ha}$. The largest rapeseed producers in the world include Canada (21,328,000 tons), China (13,274,000 tons), India (7,917,000 tons), France (5,200,000 tons), Australia (4,313,230 tons), Germany (4,275,600 tons), and Poland (2,697,265 tons) [7].

There are many factors that influence the size and quality of rapeseed and other crops. These include climatic and soil factors, sowing-cultivation-harvesting technologies, plant variety, and fertilization level [8]. Moreover, the mentioned factors are directly or indirectly related to each other, and their effect on the final crop yield is often not thoroughly studied. Therefore, prediction models supporting decision-making processes throughout the entire plant cultivation stages are increasingly used for data analysis to determine the potential yield before harvest. Such actions are aimed at optimizing production in terms of consumption of all production means which in turn maximize yield and financial profits while minimizing inputs.

In recent years, an increase in the use of prediction models in agriculture has been observed. In particular, tools based on artificial intelligence-artificial neural networks (ANN), giving significantly lower prediction errors than in case of statistical methods-are very popular. Therefore, crop yield models are implemented in computer applications for precision agriculture and are becoming an important element of decision support systems [9-18].

Most often, quantitative data is used for model building, which makes it easier to choose the modeling method. However, there are situations that require a different forecasting approach, which complicates the model building process. The use of combined data (quantitative and qualitative) may in consequence give a better result than in case of only one type of data (only quantitative or only qualitative). Therefore, the authors of this work, encouraged by previous research results $[11,19,20]$, have undertaken the construction and analysis of winter rapeseed yield models based on quantitative and qualitative data. The produced models can be used to simulate the crop in the current agrotechnical season before harvesting. The main assumption is to achieve MAPE (mean absolute percentage error) of up to $7 \%$.

Some of the developed forecasting models predict yields too late, only a few days before harvesting [21]. Al-Gaadi et al. [21] attempted to correlate the final potato tuber yield, i.e., basing on samples taken three days before harvest, with the results of vegetative indices during plant growth. The results of the study showed that the difference between the predicted yield values and actual, observed values was small, as it did not exceed $15 \%$. Of course, crop yield control from air and satellite level is valuable in agricultural production [22], but requires the use of specialized equipment and software. In addition, due to the frequent association of yield with local spectral characteristics of plants, such models can only be used in the region for which they were developed [23].

Yield predictions based on readily available agronomic and meteorological data made at relatively early and key stages of plant growth and development have a greater contribution to conscious plantation control [20]. During the winter rapeseed vegetation, five critical stages of seed yield formation are indicated, i.e., autumn vegetation, spring re-vegetation, formation of the main and side shoots, flowering, growth of pods, and maturation. While yield prediction in the first two phases may seem too early, the estimation of seed yield after formation of the main and side shoots, flowering, growth of pods and maturation stage, provides interesting, preliminary information about the actual potential yielding of plants in situ.

In the construction of forecasting models, not all available independent variables determining the scale of plant yielding should be taken into account. A big practical problem is combining the vegetation process of plants according to the widely used $\mathrm{BBCH}$ scale (Biologische Bundesanstalt, Bundessortenamt 
und $\mathrm{CHemische} \mathrm{Industrie)} \mathrm{with} \mathrm{the} \mathrm{dynamically} \mathrm{changing} \mathrm{production} \mathrm{conditions} \mathrm{[24-26].} \mathrm{Operating}$ on the $\mathrm{BBCH}$ scale allows for relatively reliable analyses, however precise collection of such data during vegetation is often simply impossible. This would require farmers to regularly observe the plantations and meticulously record the progress of vegetation. Only those farms that manage a small area and cultivate one or two varieties would have a chance to succeed. In the case of cultivating several varieties on a dozen or several dozen areas of fields simultaneously, very accurate monitoring of development phases causes problems. Therefore, in many works, the authors of the models use specific dates of the calendar year, which correspond to key developmental phases in typical years $[10,11,20]$.

\section{Materials and Methods}

The research place and material was described in [19]. However, additional qualitative data were used to build predictive models (Table 1, Table 2). All field data took into consideration 8 years of research (from 2008 to 2015), from winter rapeseed fields located in Poland, in the central and southwestern part of Greater Poland (Figure 1). In total, data from 328 fields were collected, which were divided into two sets (Table 1). Set A (292 fields) from the first seven years was the basis for model development, while set B (36 fields) from the last year of research was used to validate the constructed models and determine yield prediction errors.

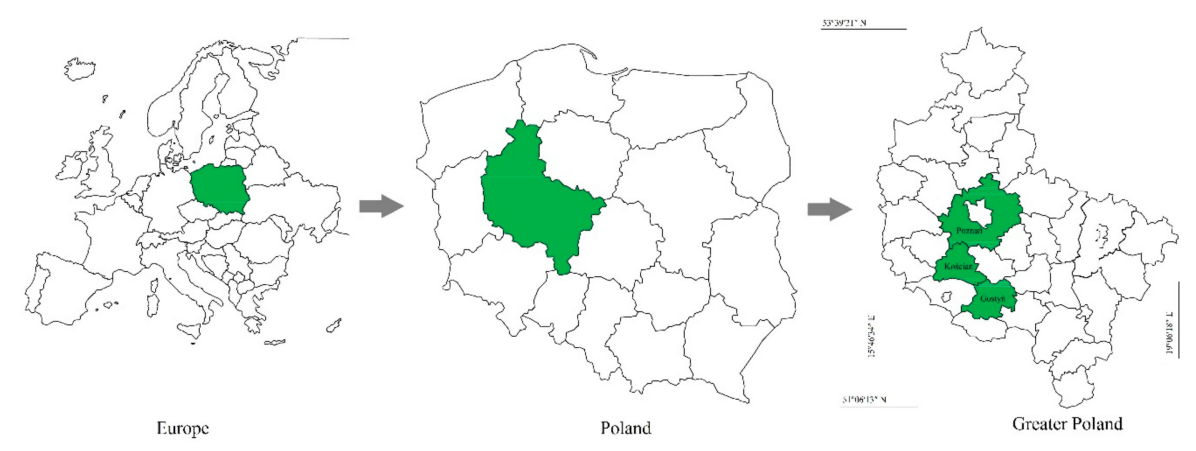

Figure 1. Research area-Greater Poland, Poland (redraw from [19]).

Table 1. The number of productive fields of winter rapeseed divided into two sets, A and B [19].

\begin{tabular}{ccccccccc}
\hline & \multicolumn{1}{c}{ Set A } & Set B \\
\hline Year & $\mathbf{2 0 0 8}$ & $\mathbf{2 0 0 9}$ & $\mathbf{2 0 1 0}$ & $\mathbf{2 0 1 1}$ & $\mathbf{2 0 1 2}$ & $\mathbf{2 0 1 3}$ & $\mathbf{2 0 1 4}$ & $\mathbf{2 0 1 5}$ \\
\hline Number of fields & 32 & 49 & 48 & 50 & 45 & 28 & 40 & 36 \\
\hline
\end{tabular}

Basic meteorological data was necessary for the construction of predictive models, and the data was obtained from meteorological stations located near fields from which empirical data was collected. Air temperature and atmospheric precipitation were divided into those obtained in the previous year (from September 1 to December 31) and from the current agrotechnical year. Meteorological data for the current year have been additionally divided into shorter periods depending on the model: from January 1 to April 15, from April 1 to April 30, from May 1 to May 31 and from June 1 to June 30.

The neural predictive model construction has been made on the basis of three predicted dates of a calendar year: April 15, May 31 and June 30. They have been named respectively QQWR15_4 (QuantitativeQualitativeWinterRapeseed15_April), QQWR31_5 and QQWR30_6. The prediction dates proposed allow easier control of winter rapeseed yield. They were chosen approximately to the course of key vegetation phases in average years: i.e., April 15-inflorescence emergence, May 31-development and formation of pods, June 30-technical maturity.

The models took into consideration those factors (independent variables) that affect crop yields and are widely available to agricultural producers (Table 2). The following approach for winter rapeseed yield prediction allows forecasting and simulation of estimated yields directly before harvesting, in the same agricultural year. 
Table 2. Data structure in the neural prediction models.

\begin{tabular}{|c|c|c|c|c|c|c|}
\hline Symbol & $\begin{array}{c}\text { Unit of } \\
\text { Measure }\end{array}$ & Variable Name & $\begin{array}{c}\text { Model } \\
\text { QQWR15_4 }\end{array}$ & $\begin{array}{c}\text { Model } \\
\text { QQWR31_5 }\end{array}$ & $\begin{array}{c}\text { Model } \\
\text { QQWR30_6 }\end{array}$ & The Scope of Data \\
\hline \multicolumn{7}{|c|}{ Quantitative data } \\
\hline R9-12_PY & $\mathrm{mm}$ & $\begin{array}{l}\text { The sum of precipitation from September } \\
1 \text { to December } 31 \text { of the previous year } \\
\text { The average air temperature from }\end{array}$ & + & + & + & $63-234$ \\
\hline T9-12_PY & ${ }^{\circ} \mathrm{C}$ & $\begin{array}{l}\text { September } 1 \text { to December } 31 \text { of the } \\
\text { previous year }\end{array}$ & + & + & + & $4.9-9.4$ \\
\hline R1-4_CY & $\mathrm{mm}$ & $\begin{array}{c}\text { The sum of precipitation from January } 1 \\
\text { to April } 15 \text { of the current year }\end{array}$ & + & + & + & $59-185$ \\
\hline T1-4_CY & ${ }^{\circ} \mathrm{C}$ & $\begin{array}{l}\text { The average air temperature from } \\
\text { January } 1 \text { to April } 15 \text { of the current year }\end{array}$ & + & + & + & $-0.4-4.9$ \\
\hline $\mathrm{R} 4 \_\mathrm{CY}$ & $\mathrm{mm}$ & $\begin{array}{c}\text { The sum of precipitation from April } 1 \text { to } \\
\text { April } 30 \text { of the current year }\end{array}$ & - & + & + & $8.7-60.4$ \\
\hline T4_CY & ${ }^{\circ} \mathrm{C}$ & $\begin{array}{l}\text { The average air temperature from April } \\
1 \text { to April } 30 \text { of the current year }\end{array}$ & - & + & + & $5.9-12.2$ \\
\hline R5_CY & $\mathrm{mm}$ & $\begin{array}{c}\text { The sum of precipitation from May } 1 \text { to } \\
\text { May } 31 \text { of the current year }\end{array}$ & - & + & + & $14.2-132.5$ \\
\hline T5_CY & ${ }^{\circ} \mathrm{C}$ & $\begin{array}{c}\text { The average air temperature from May } 1 \\
\text { to May } 31 \text { of the current year }\end{array}$ & - & + & + & $11.8-16.2$ \\
\hline R6_CY & $\mathrm{mm}$ & $\begin{array}{l}\text { Total precipitation from June } 1 \text { to June } 30 \\
\text { of the current year }\end{array}$ & - & - & + & $15-121$ \\
\hline T6_CY & ${ }^{\circ} \mathrm{C}$ & $\begin{array}{c}\text { The average air temperature from June } 1 \\
\text { to June } 30 \text { of the current year }\end{array}$ & - & - & + & $14.2-19.6$ \\
\hline N_LY & $\mathrm{kg} \mathrm{ha}^{-1}$ & $\begin{array}{c}\text { The sum of } \mathrm{N} \text { fertilization - autumn in } \\
\text { the previous year }\end{array}$ & + & + & + & $0-41$ \\
\hline N_CY & $\mathrm{kg} \mathrm{ha}^{-1}$ & $\begin{array}{c}\text { The sum of } \mathrm{N} \text { fertilization - spring in the } \\
\text { current year }\end{array}$ & + & + & + & $0-175$ \\
\hline P2O5_CY & $\mathrm{kg} \mathrm{ha}^{-1}$ & $\begin{array}{l}\text { The sum of } \mathrm{P}_{2} \mathrm{O}_{5} \text { fertilization in the } \\
\text { current year }\end{array}$ & + & + & + & $0-104$ \\
\hline K2O_CY & $\mathrm{kg} \mathrm{ha}^{-1}$ & $\begin{array}{c}\text { The sum of } \mathrm{K}_{2} \mathrm{O} \text { fertilization in the } \\
\text { current year }\end{array}$ & + & + & + & $0-234$ \\
\hline MGO_CY & $\mathrm{kg} \mathrm{ha}^{-1}$ & $\begin{array}{l}\text { The sum of MgO fertilization in the } \\
\text { current year }\end{array}$ & + & + & + & $0-298$ \\
\hline SO3_CY & $\mathrm{kg} \mathrm{ha}^{-1}$ & $\begin{array}{l}\text { The sum of } \mathrm{SO}_{3} \text { fertilization in the } \\
\text { current year }\end{array}$ & + & + & + & $14-115$ \\
\hline B_CY & $\mathrm{gha}^{-1}$ & $\begin{array}{c}\text { The sum of B fertilization in the current } \\
\text { year }\end{array}$ & + & + & + & $0-3.66$ \\
\hline CU_CY & $\mathrm{g} \mathrm{ha}^{-1}$ & $\begin{array}{c}\text { The sum of } \mathrm{Cu} \text { fertilization in the current } \\
\text { year }\end{array}$ & + & + & + & $10-487$ \\
\hline MN_CY & $\mathrm{g} \mathrm{ha}^{-1}$ & $\begin{array}{c}\text { The sum of Mn fertilization in the } \\
\text { current year }\end{array}$ & + & + & + & $70-600$ \\
\hline MO_CY & $\mathrm{g} \mathrm{ha}^{-1}$ & $\begin{array}{c}\text { The sum of Mo fertilization in the } \\
\text { current year }\end{array}$ & + & + & + & $0-60$ \\
\hline ZN_CY & $\mathrm{g} \mathrm{ha}^{-1}$ & $\begin{array}{c}\text { The sum of } \mathrm{Zn} \text { fertilization in the current } \\
\text { year }\end{array}$ & + & + & + & $9-226$ \\
\hline DOF_PY & $\mathrm{tha}^{-1}$ & $\begin{array}{c}\text { The dose of organic fertilizer in the } \\
\text { previous year }\end{array}$ & + & + & + & $0-41$ \\
\hline \multicolumn{7}{|c|}{ Qualitative data } \\
\hline KOF_PY & word & $\begin{array}{c}\text { The kind of organic fertilizer in the } \\
\text { previous year }\end{array}$ & + & + & + & $\begin{array}{c}\text { No, } \\
\text { Livestock manure, } \\
\text { Chicken manure }\end{array}$ \\
\hline LF_PY & word & The liming of a field in the previous year & + & + & + & $\begin{array}{l}\text { Yes, } \\
\text { No }\end{array}$ \\
\hline ST_PY & word & The soil tillage in the previous year & + & + & + & $\begin{array}{c}\text { Aggregate cultivator, } \\
\text { Shallow tillage, } \\
\text { Deep tillage, } \\
\text { Ploughing }\end{array}$ \\
\hline KSD_PY & word & $\begin{array}{c}\text { The kind of sowing date in the } \\
\text { previous year }\end{array}$ & + & + & + & $\begin{array}{c}\text { Early, } \\
\text { Optimal Tardy }\end{array}$ \\
\hline TF_PY & word & The type of forecrop in the previous year & + & + & + & $\begin{array}{c}\text { Winter rapeseed, } \\
\text { Winter wheat, } \\
\text { Winter triticale, } \\
\text { Winter barley, } \\
\text { Spring barley, } \\
\text { Oat, Rye }\end{array}$ \\
\hline
\end{tabular}

"+"- the variable exists in the model, "-" - the variable does not exist in the model.

Tables 1 and 2 present independent variables in qualitative and quantitative research that were the basis for the construction of each of the three neural models. The choice of the network topology was guided by the results of earlier studies $[10,11,20]$. In addition, the network's ability to approximate and generalize, considering the network error rate, was taken into account. Each constructed neural model QQWR15_4, QQWR31_5, and QQWR30_6 was a result of learning 10,000 networks, one of which was selected with the best parameters. Basic measures of network quality were determined-standard deviation, mean error, deviation error, mean absolute error, quotient of deviation, and correlation. 
The best model was chosen based on the lowest mean absolute error value and the largest correlation value. Automatic network designer from Statistica v7.1 (StatSoft Inc., Tulsa, OK, USA) was used for neural network building. The 292 data set was divided into three sets: training, validation and test. The sets were divided into $70 \%-15 \%-15 \%$ proportion (204-44-44 cases in each set).

In the next stage, the obtained neural models QQWR15_4, QQWR31_5, and QQWR30_6 were validated, comparing the results of model prediction with real data from set $B$ ( 36 cases from 2015). Data from set B were not considered in construction of QQWR15_4, QQWR31_5, and QQWR30_6 neural models. In order to determine the prediction errors of winter rapeseed yields, the difference between the observed and the predicted value was performed. This method is widely described in the literature [20,27-30]. Determination of the quality of predictions was based on the error measures (Equations (1)-(4)):

RAE—relative approximation error;

$$
R A E=\sqrt{\frac{\sum_{i=1}^{n}\left(y_{i}-\hat{y}_{i}\right)^{2}}{\sum_{i=1}^{n}\left(y_{i}\right)^{2}}}
$$

RMS—root mean square error;

$$
R M S=\sqrt{\frac{\sum_{i=1}^{n}\left(y_{i}-\hat{y}_{i}\right)^{2}}{n}}
$$

MAE—mean absolute error;

$$
M A E=\frac{1}{n} \sum_{i=1}^{n}\left|y_{i}-\hat{y}_{i}\right|
$$

MAPE—mean absolute percentage error;

$$
M A P E=\frac{1}{n} \sum_{i=1}^{n}\left|\frac{y_{i}-\hat{y}_{i}}{y_{i}}\right| \times 100 \%
$$

where

n-number of observations,

$y_{i}$-actual values obtained during research,

$\hat{y}_{i}$-values given by the model.

The last stage of the research was the sensitivity analysis of the neural network. This analysis gives the opportunity to examine all independent variables in each produced neural model QQWR15_4, QQWR31_5, and QQWR30_6. As a result of this test, the information about the importance (rank) of each measure is obtained. The greater the numerical value of a given feature (error quotient), the greater the impact on winter rapeseed yield. All values below 1 indicate a low impact on the yield of the given independent variable and can be removed from the model.

\section{Results}

According to the presented methodology of neural model building, 1 of 10,000 models was selected for analysis considering a specific forecast date. These models were chosen based on the best qualitative parameters of the neural network. Detailed information on the quality and structure of selected neural models QQWR15_4, QQWR31_5, and QQWR30_6 are presented in Table 3. 
Table 3. The quality and structure of the neural models produced.

\begin{tabular}{cccc}
\hline & QQWR15_4 & QQWR31_5 & QQWR30_6 \\
\hline Neural network & MLP & MLP & MLP \\
structure & $21: 33-15-9-1: 1$ & $25: 37-16-16-1: 1$ & $27: 39-10-1: 1$ \\
Learning error & 0.0515 & 0.0914 & 0.0932 \\
Validation error & 0.0898 & 0.0987 & 0.0837 \\
Test error & 0.1033 & 0.1042 & 0.1386 \\
Mean & 3.3627 & 3.3626 & 3.3626 \\
Standard deviation & 1.0703 & 1.0703 & 1.0703 \\
Average error & -0.0126 & 0.0924 & 0.0205 \\
Deviation error & 0.4087 & 0.5578 & 0.5548 \\
Mean Absolute error & 0.2870 & 0.4353 & 0.4118 \\
Quotient deviations & 0.3818 & 0.5211 & 0.5183 \\
Correlation & 0.9245 & 0.8534 & 0.8552 \\
\hline
\end{tabular}

The next stage of the analysis was validation of the produced models. The observed yield from set $B$ was compared to the results of prediction of all produced models. For this purpose, formulas (1-4) were applied and the results of model validation are included in Table 4.

Table 4. Measures prediction of analyzed neural models.

\begin{tabular}{ccccc}
\hline Model & RAE (-) & RMS (t ha-1) & MAE (t ha-1) & MAPE (\%) \\
\hline QQWR15_4 & 0.098 & 0.43 & 0.37 & 9.87 \\
QQWR31_5 & 0.068 & 0.29 & 0.25 & 6.88 \\
QQWR30_6 & 0.076 & 0.32 & 0.28 & 7.69 \\
\hline
\end{tabular}

Network Sensitivity Analysis

The sensitivity analysis of the produced neural models was the last stage of calculations. For each model QQWR15_4, QQWR31_5, and QQWR30_6 the error quotient and the rank were determined, they are presented in Table 5.

Table 5. Sensitivity analysis of neural networks.

\begin{tabular}{|c|c|c|c|c|c|c|}
\hline \multirow[t]{3}{*}{ Variable } & \multicolumn{6}{|c|}{ Model } \\
\hline & \multicolumn{2}{|c|}{ QQWR15_4 } & \multicolumn{2}{|c|}{ QQWR31_5 } & \multicolumn{2}{|c|}{ QQWR30_6 } \\
\hline & quotient & rank & quotient & rank & quotient & rank \\
\hline R9-12_PY & 1.549 & 4 & 1.077 & 5 & 1.029 & 10 \\
\hline T9-12_PY & 1.224 & 9 & 1.007 & 20 & 1.027 & 11 \\
\hline R1-4_CY & 1.314 & 5 & 1.028 & 9 & 1.018 & 14 \\
\hline T1-4_CY & 1.129 & 13 & 1.027 & 10 & 1.012 & 20 \\
\hline R4_CY & - & - & 1.041 & 7 & 1.036 & 8 \\
\hline T4_CY & - & - & 1.012 & 17 & 1.021 & 13 \\
\hline R5_CY & - & - & 1.068 & 6 & 1.078 & 6 \\
\hline T5_CY & - & - & 1.237 & 2 & 1.228 & 2 \\
\hline R6_CY & - & - & - & - & 1.016 & 17 \\
\hline T6_CY & - & - & - & - & 1.012 & 19 \\
\hline N_LY & 1.099 & 15 & 1.016 & 15 & 1.010 & 21 \\
\hline N_CY & 1.107 & 14 & 1.007 & 19 & 1.000 & 26 \\
\hline P2O5_CY & 1.027 & 18 & 1.013 & 16 & 0.989 & 27 \\
\hline K2O_CY & 1.012 & 21 & 0.994 & 24 & 1.003 & 25 \\
\hline MGO_CY & 1.232 & 7 & 1.009 & 18 & 1.017 & 16 \\
\hline SO3_CY & 1.081 & 16 & 1.038 & 8 & 1.018 & 15 \\
\hline B_CY & 1.150 & 11 & 1.027 & 11 & 1.008 & 22 \\
\hline CU__CY & 1.014 & 20 & 1.005 & 21 & 1.004 & 23 \\
\hline MN_CY & 1.018 & 19 & 0.994 & 25 & 1.015 & 18 \\
\hline MO_CY & 1.637 & 3 & 1.016 & 14 & 1.130 & 5 \\
\hline ZN_CY & 1.078 & 17 & 0.999 & 23 & 1.003 & 24 \\
\hline DOF_PY & 1.144 & 12 & 1.002 & 22 & 1.029 & 9 \\
\hline KOF_PY & 1.228 & 8 & 1.026 & 12 & 1.040 & 7 \\
\hline LF_PY & 1.169 & 10 & 1.016 & 13 & 1.025 & 12 \\
\hline ST_PY & 1.294 & 6 & 1.098 & 4 & 1.144 & 4 \\
\hline KSD_PY & 2.273 & 1 & 1.251 & 1 & 1.435 & 1 \\
\hline TF_PY & 1.846 & 2 & 1.204 & 3 & 1.150 & 3 \\
\hline
\end{tabular}


By considering the results obtained in the previous stages, a decision was made to perform additional analyses and visualizations between the observed yield values and the yield values predicted by the QQWR15_4, QQWR31_5, and QQWR30_6 models. The results of the analyses are presented in Figure 2. The QQWR31_5 model obtained the highest coefficient of determination, the value of which was $R^{2}=0.69$. Slightly lower $R^{2}$ values were calculated for models QQWR15_4 and QQWR30_6, which were 0.47 and 0.60, respectively.

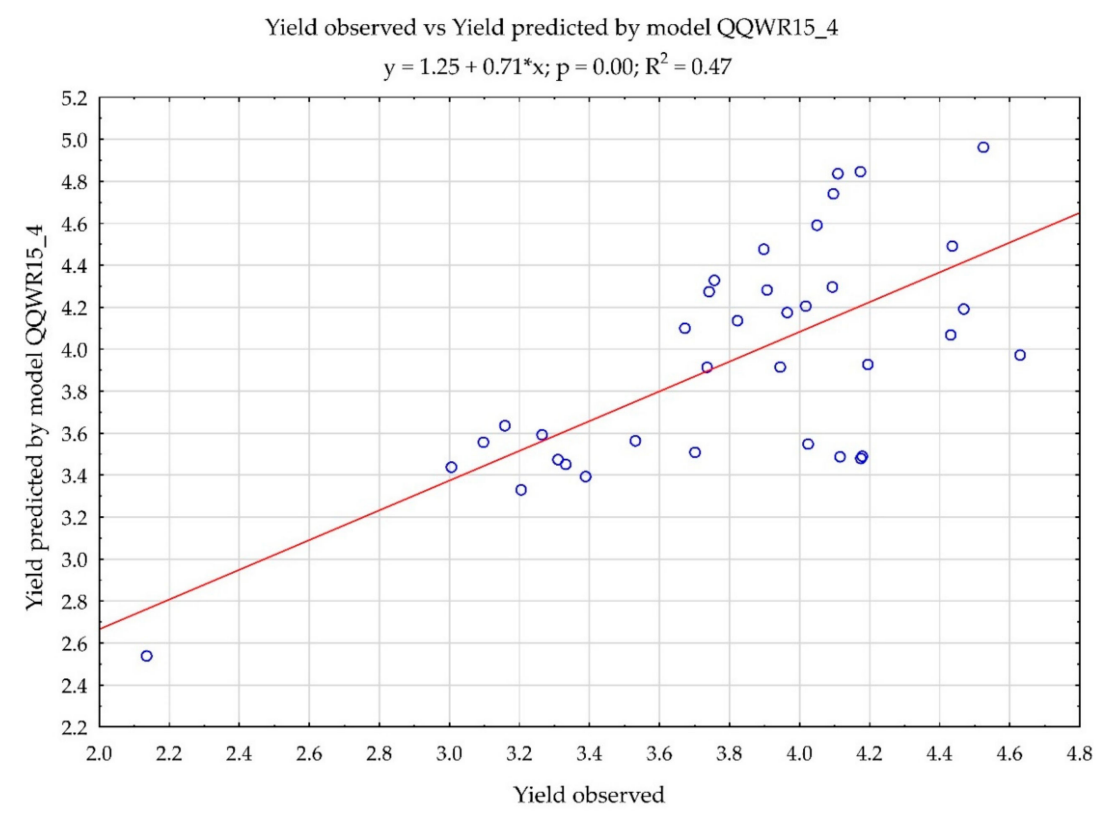

(a)

Yield observed vs Yield predicted by model QQWR31_5 $y=0.98+0.75^{*} x ; p=0.00 ; R^{2}=0.69$

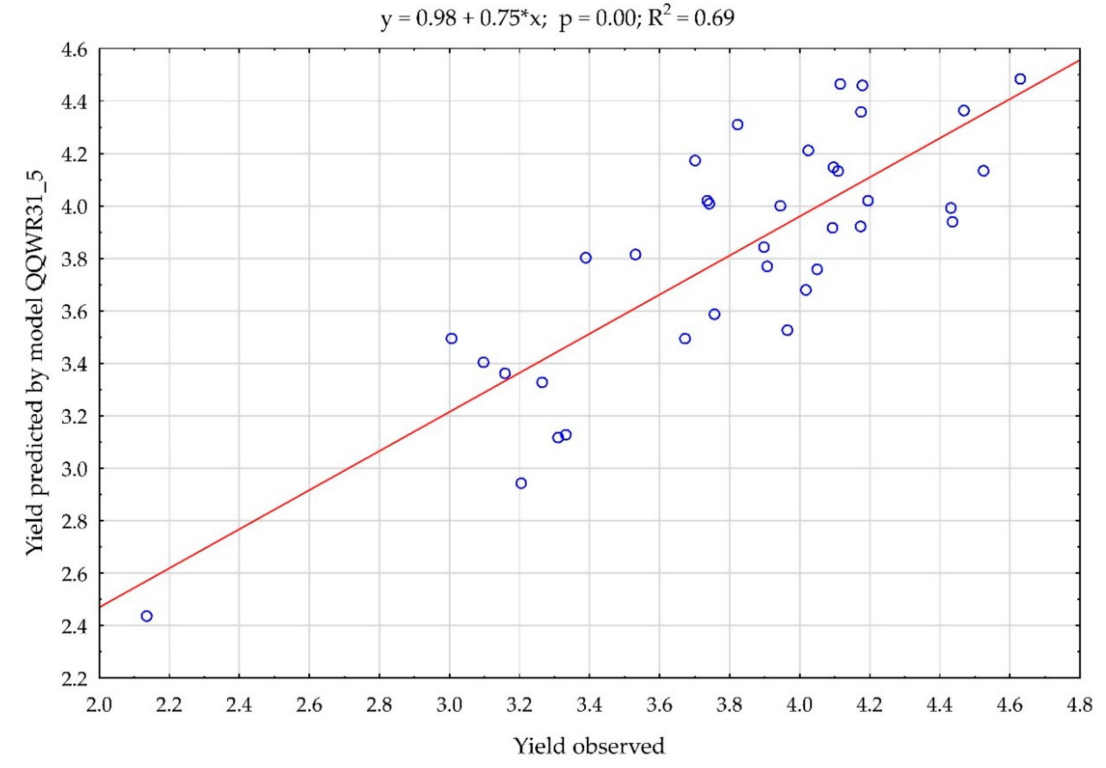

(b)

Figure 2. Cont. 


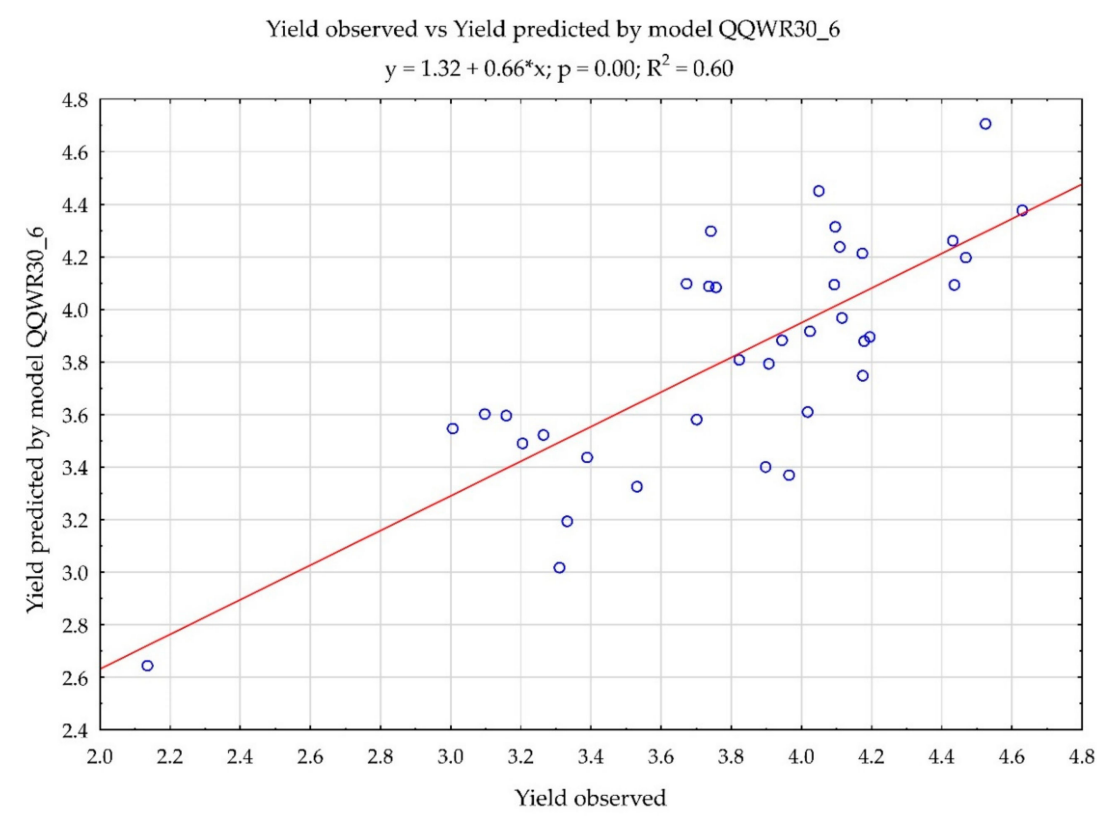

(c)

Figure 2. Relation between the observed and predicted yield $\left(\mathrm{t} \mathrm{ha}^{-1}\right)$ by model: (a) QQWR15_4, (b) QQWR31_5 and (c) QQWR30_6.

\section{Discussion}

Many different modeling methods are applied to predict crop yield. Regardless of the method chosen, it is necessary to collect empirical data from the past. It is assumed that the models will have a lower forecast error as the number of years and the number of data on which they are based increase [10]. A large number of factors affecting crop yields determine the choice of the optimal method of analysis. Many of the independent variables can only be obtained from specialized tests. Apart from data availability, another problem in modeling is their format and structure. While quantitative data are most often used, available qualitative data are often difficult to implement in produced models. Therefore, the decision was made to integrate quantitative and qualitative data. Each model produced as part of the following research work, i.e., QQWR15_4, QQWR31_5, and QQWR30_6 is based on both types of data and allows making yield forecasts in the current agrotechnical year before harvesting. In addition, it was assumed that a good model will have a low MAPE and will be up to $7 \%$. Artificial neural networks, which are non-linear modeling methods, were used to implement the assumed prediction error. As a rule, they give better forecast results than classical mathematical models and enable combining quantitative and qualitative data. Most often, MLP (multi-layer perceptron) topology network is used in forecasting, which was implemented to build three models QQWR15_4, QQWR31_5, and QQWR30. Each model is based on 21, 25, and 27 independent variables, respectively, which include 5 qualitative variables (Table 2).

Validation of produced neural models for predicting winter rapeseed yields is based on determining the quality of forecasts using four measures, i.e., RAE, RMS, MAE, and MAPE. The error values for all produced neural models are shown in Table 4 . However, the most commonly used indicator for determining the forecast error is MAPE. The lowest error values of this indicator were obtained only for the QQWR31_5 neural model based on the MLP network with the structure 25: 37-16-16-1: 1, which was $6.88 \%$. The same time period (January-May) obtained the lowest error in prediction of winter wheat yield in work [20]. In the following work, the MAPE error rate was assumed to be up to $7 \%$. This means that the other two models QQWR15_4 and QQWR30 did not achieve the assumed error rate because their MAPE was higher and amounted to 9.87 and 7.69, respectively.

The network sensitivity analysis was another element of performed calculations. It took into account all neural networks produced. The independent variable "The kind of sowing date in the 
previous year" (KSD_PY) (Table 5) obtained the highest rank 1 in each network, which is consistent with literature sources [31-34]. In the QQWR31_5 model, the error quotient was 1.2510. Interestingly enough, the independent variable, "The average air temperature from May 1 to May 31 of the current year" (T5_CY) came second in this model, which took a lower value of 1.2367. A similar situation was also observed in QQWR30 model. As it was investigated in [20], the dominant influence of atmospheric factors in predicting winter wheat yield did not correspond completely to prediction of winter rapeseed yield. In the QQWR15_4 model, the independent feature "The type of forecrop in the previous year" (TF_PY) came second. However, as indicated earlier, QQWR15_4 and QQWR30 did not achieve the assumed MAPE rate. Despite the differences in the results of individual models, it can be explicitly indicated that qualitative data had a dominant impact on the forecast of winter rapeseed yield. Other authors studying this species [35-37] have also confirmed that sowing date is a very important feature. Rapeseed is very sensitive to date of sowing, because its dynamic development takes place at a temperature exceeding $12{ }^{\circ} \mathrm{C}$. In the area studied, such temperatures usually occur at the turn of the second and third decade of August. Sowing that is too late, taking place in September or October, causes lower aboveground matter development in plants. Their growth cone contains insufficient buds of future generative organs. On the other hand, too early sowing poses the risk of excessive outgrowth before winter, which is characterized by a large above-ground matter, susceptible to damage and freezing. Failure to meet the proper sowing date is almost always associated with poorer wintering of plants. The maximum delay in sowing, which does not influence reduction in yield, is $5-7$ days.

Comparing the predicted yield to observed yield (Figure 2), the best fit was for QQWR31_5 model, with $R^{2}=0.69$. This confirms the right assumption of the maximum MAPE of up to $7 \%$.

\section{Conclusions}

The results of the present work clearly indicate the possibility of using neural models to predict the yield of winter rapeseed in practice, basing on quantitative and qualitative data. For this purpose, particularly useful is the QQWR31_5 model, whose MAPE is $6.88 \%$ and its determination coefficient $R^{2}$ is 0.69 . It is the only model that met the assumptions of the work regarding the maximum MAPE of up to $7 \%$. In addition, neural network sensitivity analysis revealed that "The kind of sowing date in the previous year" (KSD_PY) had the greatest impact on winter rapeseed yield. Such result was obtained for all analyzed models. The neural models presented in the paper can be applied in precision agriculture as a key factor in decision making systems.

Further research should be aimed at optimizing the produced neural models in two directions. As part of the first direction, independent variables should be reduced while simultaneously maintaining the MAPE rate. The second direction is to obtain more empirical data from regions with different soil and climatic conditions. Such actions will aid in expanding the field scope of model practical application and should positively affect the accuracy of forecast.

Author Contributions: Conceptualization, G.N.; Data curation, G.N., M.P., K.W., M.A. and A.K.-K.; Formal analysis, G.N., M.P., J.W., M.A., K.P. and A.C.-K.; Funding acquisition, G.N. and J.W.; Investigation, G.N.; Methodology, G.N., M.P. and A.C.-K.; Project administration, G.N.; Resources, R.K., K.W., A.C.-K. and A.K.-K.; Software, J.W., R.K. and A.K.-K.; Supervision, G.N. and J.W.; Validation, M.P., M.A. and A.C.-K.; Writing-original draft, G.N., M.P. and J.W.; Writing-review \& editing, R.K., K.W., K.P. and A.K.-K.

Acknowledgments: The publication was co-financed within the framework of Ministry of Science and Higher Education programme as "Regional Initiative Excellence" in years 2019-2022, Project No. 005/RID/2018/19.

Conflicts of Interest: The authors declare no conflict of interest. The funders had no role in the design of the study; in the collection, analyses, or interpretation of data; in the writing of the manuscript, or in the decision to publish the results. 


\section{References}

1. Shahid, M.; Cai, G.; Zu, F.; Zhao, Q.; Qasim, M.U.; Hong, Y.; Fan, C.; Zhou, Y. Comparative Transcriptome Analysis of Developing Seeds and Silique Wall Reveals Dynamic Transcription Networks for Effective Oil Production in Brassica napus L. Int. J. Mol. Sci. 2019, 20, 1982. [CrossRef] [PubMed]

2. Zannis, T.C.; Papagiannakis, R.G.; Pariotis, E.G.; Kourampas, M.I. Experimental Study of DI Diesel Engine Operational and Environmental Behavior Using Blends of City Diesel with Glycol Ethers and RME. Energies 2019, 12, 1547. [CrossRef]

3. Li, Y.; Bundeesomchok, K.; Rakotomanomana, N.; Fabiano-Tixier, A.-S.; Bott, R.; Wang, Y.; Chemat, F. Towards a Zero-Waste Biorefinery Using Edible Oils as Solvents for the Green Extraction of Volatile and Non-Volatile Bioactive Compounds from Rosemary. Antioxidants 2019, 8, 140. [CrossRef] [PubMed]

4. Dezfouli, P.M.; Sedghi, M.; Shariatpanahi, M.E.; Niazian, M.; Alizadeh, B. Assessment of general and specific combining abilities in doubled haploid lines of rapeseed (Brassica napus L.). Ind. Crop. Prod. 2019, 141, 111754. [CrossRef]

5. Saluja, R.K.; Kumar, V.; Sham, R. Stability of biodiesel-A review. Renew. Sustain. Energy Rev. 2016, 62, 166-181. [CrossRef]

6. Bartoszek, K. Usefulness of MODIS data for assessment of the growth and development of winter oilseed rape. Zemdirb.-Agric. 2014, 101, 445-452. [CrossRef]

7. FAO Food and Agriculture Organization of the United Nations (FAO). FAOSTAT Online Statistical Service. Available online: http://faostat.fao.org (accessed on 5 September 2019).

8. Khairunniza-Bejo, S.; Mustaffha, S.; Ishak, W.; Ismail, W. Application of Artificial Neural Network in Predicting Crop Yield: A Review. J. Food Sci. Eng. 2014, 4, 1-9.

9. Liu, Y.; Zhang, S.; Chen, X.; Wang, J. Artificial Combined Model Based on Hybrid Nonlinear Neural Network Models and Statistics Linear Models-Research and Application for Wind Speed Forecasting. Sustainability 2018, 10, 4601. [CrossRef]

10. Niedbała, G.; Kozłowski, R.J. Application of Artificial Neural Networks for Multi-Criteria Yield Prediction of Winter Wheat. J. Agric. Sci. Technol. 2019, 21, 51-61.

11. Niedbała, G. Simple model based on artificial neural network for early prediction and simulation winter rapeseed yield. J. Integr. Agric. 2019, 18, 54-61. [CrossRef]

12. Niedbała, G.; Mioduszewska, N.; Mueller, W.; Boniecki, P.; Wojcieszak, D.; Koszela, K.; Kujawa, S.; Kozłowski, R.J.; Przybył, K. Use of computer image analysis methods to evaluate the quality topping sugar beets with using artificial neural networks. In Proceedings of the SPIE, Eighth International Conference on Digital Image Processing (ICDIP 2016), Chengdu, China, 20-22 May 2016; Volume 10033, p. 100332M.

13. Taner, A.; Öztekin, Y.; Tekgüler, A.; Sauk, H.; Duran, H. Classification of Varieties of Grain Species by Artificial Neural Networks. Agronomy 2018, 8, 123. [CrossRef]

14. Mohammadi Torkashvand, A.; Ahmadi, A.; Gómez, P.A.; Maghoumi, M. Using artificial neural network in determining postharvest LIFE of kiwifruit. J. Sci. Food Agric. 2019, 99, 5918-5925. [CrossRef] [PubMed]

15. Abdipour, M.; Ramazani, S.H.R.; Younessi-Hmazekhanlu, M.; Niazian, M. Modeling Oil Content of Sesame (Sesamum indicum L.) Using Artificial Neural Network and Multiple Linear Regression Approaches. JAOCS J. Am. Oil Chem. Soc. 2018, 95, 283-297. [CrossRef]

16. Abdipour, M.; Younessi-Hmazekhanlu, M.; Ramazani, S.H.R.; Omidi, A. hassan Artificial neural networks and multiple linear regression as potential methods for modeling seed yield of safflower (Carthamus tinctorius L.). Ind. Crop. Prod. 2019, 127, 185-194. [CrossRef]

17. Wojciechowski, T.; Niedbala, G.; Czechlowski, M.; Nawrocka, J.R.; Piechnik, L.; Niemann, J. Rapeseed seeds quality classification with usage of VIS-NIR fiber optic probe and artificial neural networks. In Proceedings of the 2016 International Conference on Optoelectronics and Image Processing, ICOIP, Warsaw, Poland, 10-12 June 2016.

18. Kujawa, S.; Dach, J.; Kozłowski, R.J.; Przybył, K.; Niedbała, G.; Mueller, W.; Tomczak, R.J.; Zaborowicz, M.; Koszela, K. Maturity classification for sewage sludge composted with rapeseed straw using neural image analysis. In Proceedings of the SPIE, Eighth International Conference on Digital Image Processing (ICDIP 2016), Chengdu, China, 20-22 May 2016; Volume 10033, p. 100332H.

19. Niedbała, G. Application of artificial neural networks for multi-criteria yield prediction of winter rapeseed. Sustainability 2019, 11, 533. [CrossRef] 
20. Niedbała, G.; Nowakowski, K.; Rudowicz-Nawrocka, J.; Piekutowska, M.; Weres, J.; Tomczak, R.J.; Tyksiński, T.; Pinto, A.Á. Multicriteria prediction and simulation of winter wheat yield using extended qualitative and quantitative data based on artificial neural networks. Appl. Sci. 2019, 9, 2773. [CrossRef]

21. Al-Gaadi, K.A.; Hassaballa, A.A.; Tola, E.; Kayad, A.G.; Madugundu, R.; Alblewi, B.; Assiri, F. Prediction of potato crop yield using precision agriculture techniques. PLOS ONE 2016, 11, 1-16. [CrossRef]

22. Salazar, L.; Kogan, F.; Roytman, L. Use of remote sensing data for estimation of winter wheat yield in the United States. Int. J. Remote Sens. 2007, 28, 3795-3811. [CrossRef]

23. Moriondo, M.; Maselli, F.; Bindi, M. A simple model of regional wheat yield based on NDVI data. Eur. J. Agron. 2007, 26, 266-274. [CrossRef]

24. Meier, U. Growth Stages of Mono and Dicotyledonous Plants. In BBCH Monograph; Federal Biological Research Centre for Agriculture and Forestry: Bonn, Germany, 2001.

25. Böttcher, U.; Rampin, E.; Hartmann, K.; Zanetti, F.; Flenet, F.; Morison, M.; Kage, H. A phenological model of winter oilseed rape according to the BBCH scale. Crop Pasture Sci. 2016, 67, 345-358. [CrossRef]

26. Kirkegaard, J.A.; Lilley, J.M.; Brill, R.D.; Ware, A.H.; Walela, C.K. The critical period for yield and quality determination in canola (Brassica napus L.). Field Crop. Res. 2018, 222, 180-188. [CrossRef]

27. Dar, E.A.; Brar, A.S.; Mishra, S.K.; Singh, K.B. Simulating response of wheat to timing and depth of irrigation water in drip irrigation system using CERES-Wheat model. Field Crop. Res. 2017, 214, 149-163. [CrossRef]

28. Emamgholizadeh, S.; Parsaeian, M.; Baradaran, M. Seed yield prediction of sesame using artificial neural network. Eur. J. Agron. 2015, 68, 89-96. [CrossRef]

29. Torkashvand, A.M.; Ahmadi, A.; Nikravesh, N.L. Prediction of kiwifruit firmness using fruit mineral nutrient concentration by artificial neural network (ANN) and multiple linear regressions (MLR). J. Integr. Agric. 2017, 16, 1634-1644. [CrossRef]

30. Niazian, M.; Sadat-Noori, S.A.; Abdipour, M. Modeling the seed yield of Ajowan (Trachyspermum ammi L.) using artificial neural network and multiple linear regression models. Ind. Crop. Prod. 2018, 117, 224-234. [CrossRef]

31. Jenkins, P.D.; Leitch, D.M.H. Effects of sowing date on the growth and yield of winter oil-seed rape (Brassica napus). J. Agric. Sci. 1986, 107, 405-420. [CrossRef]

32. Zhang, S.-J.; Li, L.; Zhang, C.-L. Effects of sowing date and planting density on the seed yield and oil content of winter oilseed rape. J. Appl. Ecol. 2012, 23, 1326-1332.

33. Sieling, K.; Böttcher, U.; Kage, H. Effect of Sowing Method and N Application on Seed Yield and N Use Efficiency of Winter Oilseed Rape. Agronomy 2017, 7, 21. [CrossRef]

34. Li, X.; Wu, L.; Qiu, G.; Wang, T.; Liu, C.; Yang, Y.; Feng, B.; Chen, C.; Zhang, W.; Liu, Z. Effects of Sowing Season on Agronomic Traits and Fatty Acid Metabolic Profiling in Three Brassica napus L. Cultivars. Metabolites 2019, 9, 37. [CrossRef]

35. Hocking, P.J.; Stapper, M. Effects of sowing time and nitrogen fertiliser on canola and wheat, and nitrogen fertiliser on Indian mustard. I. Dry matter production, grain yield, and yield components. Aust. J. Agric. Res. 2001, 52, 623-634. [CrossRef]

36. Robertson, M.J.; Holland, J.F.; Bambach, R. Response of canola and Indian mustard to sowing date in the grain belt of north-eastern Australia. Aust. J. Exp. Agric. 2004, 44, 43-52. [CrossRef]

37. Ratajczak, K. Effects of Growth Type, Sowing Date, and Sowing Rate on the Canopy Architecture, Protein Yields, and Oil Yields of Winter Oilseed Rape (Brassica napus L.). J. Bot. Res. 2019, 1. [CrossRef]

(C) 2019 by the authors. Licensee MDPI, Basel, Switzerland. This article is an open access article distributed under the terms and conditions of the Creative Commons Attribution (CC BY) license (http://creativecommons.org/licenses/by/4.0/). 